University of Louisville

ThinkIR: The University of Louisville's Institutional Repository

\title{
The effects of a video designed to empower parents to find the time to complete their child's speech and language homework.
}

Lana E. Ridge 1987-

University of Louisville

Follow this and additional works at: https://ir.library.louisville.edu/etd

\section{Recommended Citation}

Ridge, Lana E. 1987-, "The effects of a video designed to empower parents to find the time to complete their child's speech and language homework." (2011). Electronic Theses and Dissertations. Paper 1204. https://doi.org/10.18297/etd/1204

This Master's Thesis is brought to you for free and open access by ThinkIR: The University of Louisville's Institutional Repository. It has been accepted for inclusion in Electronic Theses and Dissertations by an authorized administrator of ThinkIR: The University of Louisville's Institutional Repository. This title appears here courtesy of the author, who has retained all other copyrights. For more information, please contact thinkir@louisville.edu. 
THE EFFECTS OF A VIDEO DESIGNED TO EMPOWER PARENTS TO FIND

THE TIME TO COMPLETE THEIR CHILD'S SPEECH AND LANGUAGE

HOMEWORK

By

Lana E. Ridge

B.S., Miami University, 2009

\author{
A Thesis \\ Submitted to the Faculty of the \\ College of Arts and Sciences of the University of Louisville \\ in Partial Fulfillment of the Requirements \\ for the Degree of
}

Master of Science

Department of Surgery

University of Louisville

Louisville, Kentucky

May 2011 

THE EFFECTS OF A VIDEO DESIGNED TO EMPOWER PARENTS TO FIND THE TIME TO COMPLETE THEIR CHILD'S SPEECH AND LANGUAGE HOMEWORK

By

$$
\text { Lana E. Ridge }
$$

B.S., Miami University, 2009

A Thesis approved on

April 13, 2011

by the following Thesis Committee:

\begin{tabular}{c}
\hline Or. Gay Masters \\
\hline Dr. Barbara Baker \\
Dr: Amy Lingo
\end{tabular}




\section{DEDICATION}

This thesis is dedicated to my creative and supportive husband, Alan Ridge,

and

to my wonderful family. 


\section{ACKNOWLEDGEMENTS}

I would like to thank Dr. Gay Masters, Dr. Barbara Baker, and Dr. Amy Lingo for their support, guidance, and patience throughout this process. I would also like to thank my husband, Alan, for all of his support and understanding during my schooling. Thank you to my praying parents, Lynn and Susie Mercer. I appreciate the Ridge family and the Smith family for all of their help. Thank you to my twin sister, Leta Mercer, for all of her support while she is also pursuing her Masters degree. Also, thank you to the Communicative Disorders Class of 2011 for all of their encouragement when I needed it. Thank You Heavenly Father for guiding my path. 


\section{ABSTRACT \\ THE EFFECTS OF A VIDEO DESIGNED TO EMPOWER PARENTS TO FIND THE TIME TO COMPLETE THEIR CHILD'S SPEECH AND LANGUAGE HOMEWORK

\author{
Lana Ridge
}

April 13, 2011

The study was completed to determine if parents' feelings of empowerment is improved after viewing a video. The video was designed to assist parents in determining appropriate time(s) to complete speech and language therapy homework. Parents from the JCPS, who had children in speech therapy, were recruited through a recruitment packet distributed by the school SLP.

Parents were to complete 3 questionnaires, each two weeks apart, on www.surveygizmo.com regarding homework. Parents were asked to view a video at the end of the first and second questionnaire.

Twenty-four percent, of the SLPs initially agreed to participate. It is known that 4 schools failed to distribute the recruitment letters. No initial questionnaires were completed. One person completed and two people partially completed the second questionnaire. No parent viewed the video.

No data was obtained to answer the research question. Implications of this study's failure to obtain data are in the discussion section. 
TABLE OF CONTENTS

PAGE

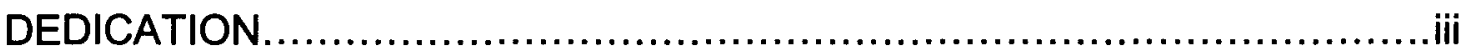

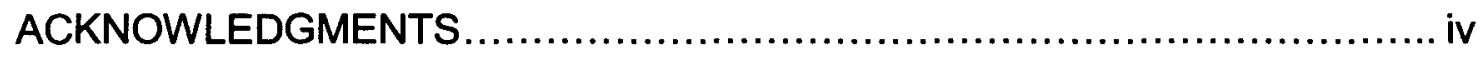

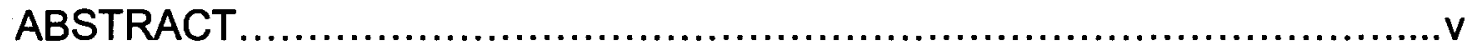

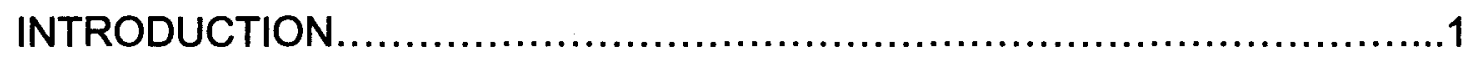

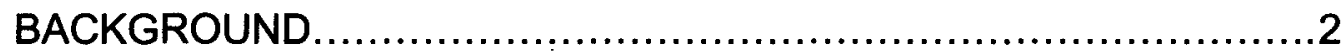

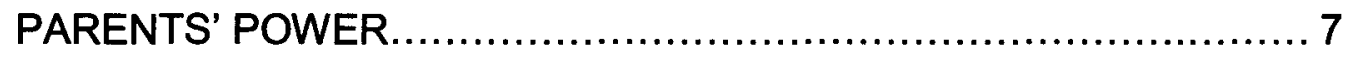

HOMEWORK ..........................................................

LITERATURE REVIEW........................................................

FAMILY FOCUSED INTERVENTIONS.................................. 10

EMPOWERING AND COACHING.......................................13

TEACHING AND TRAINING PARENTS....................................15

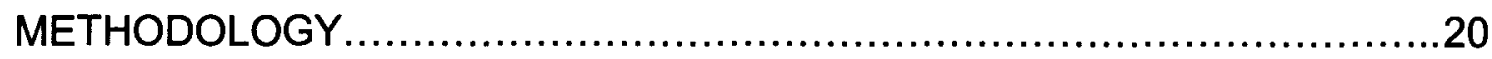

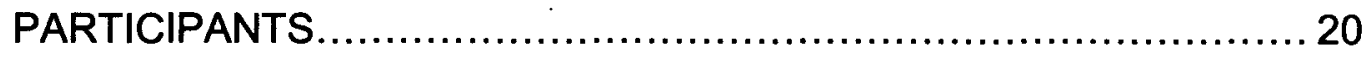

MATERIALS ................................................................. 20

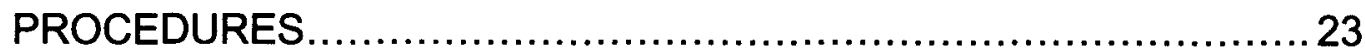

MAIN OUTCOME MEASURE.............................................26

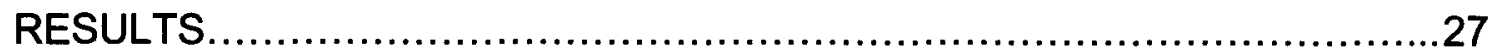

DISCUSSION................................................................... 33 


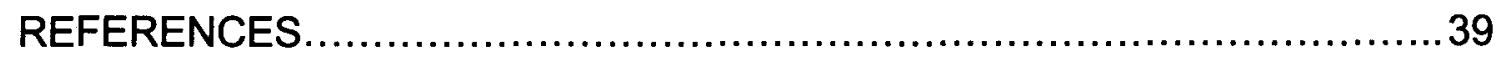

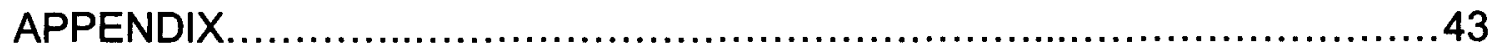

FIGURE 1- TEXT OF THE VIDEO .........................................43

FIGURE 2- QUESTIONNAIRE........................................ 47

FIGURE 3- RESPONSES FROM SECOND QUESTIONNAIRE..........52

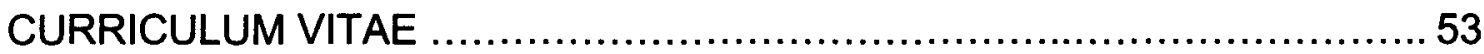




\section{INTRODUCTION}

School speech-language pathologists help school-aged children with communication and swallowing problems. They create goals for the children, along with a school team including the parents. These goals are designed to assist the child to communicate more effectively and efficiently. The therapists see the children only part time throughout the week and may ask the children to practice outside of the therapy setting. According to Understanding SpeechLanguage Pathology (2010) part of the therapy program is for parents to assist with homework. Part of the goals in speech therapy is to generalize the accomplishments made in therapy to outside settings (Roth \& Worthington, 2005 and Dwight, 2006). Generalization of goals can be part of the termination of therapy goals.

Parent participation is important because "parents are their child's first and best teacher" (Young \& Young, 2009). Numerous research supports the importance of parent integration into the therapy process. The belief that parents need to be involved as integral parts of the therapy progression is supported by various researchers (c.f. Delgado-Gaitan, 1991; Hoover-Dempsey, Bassler, \& Brissie, 1987; Lyons, O'Malley, O'Connor, \& Monaghan, 2010; and Yaruss, Coleman, \& Hammer, 2006). Not all parents/guardians take the time to complete the speech-language therapy homework. 


\section{Background}

\section{Speech therapists in the schools}

A speech-language pathologist is one who provides services for any age person who has difficulty with communication or swallowing. The communication problems could include but are not limited to the following: articulation problems (errors in the way speech sounds are produced), cognitive problems (differences in the way language is processed and formulated), voice problems (errors in the way sound is produced by the vocal folds), auditory problems (hearing loss), auditory comprehension problems (difficulty understanding spoken language), craniofacial anomalies (structural or functional changes which resulted in difficulty producing speech), pragmatic problems (difficulty understanding or expressing social or emotional communication), language problems (difficulty understanding or expressing the structure and meaning of spoken and body language), literacy problems (difficulty with reading and phonics), fluency problems (errors in regards to rate and rhythm of speech), neurological problems (brain abnormalities), receptive problems (difficulty understanding speech and language), and expressive problems (errors when speech and language are produced). The swallowing problems (dysphagia) could include but are not limited to the following: chewing food, swallowing, or avoiding reflux, which is when food comes back up the esophagus. Some dysphagia issues relate to sensory problems. The person may have oral defensiveness or may have a hyperactive gag reflex. 
A student can receive speech and language therapy services for communication and swallowing difficulties if it is determined by an Individualized Education Plan team that therapy is warranted. A speech therapist will evaluate the student's Response to Intervention (RTI). The National Center on Response to Intervention explains RTI as a plan to help students at risk for needing extra school support (National Center on Response to Intervention, n.d.). Necessary changes will be made in terms of intensity or the types of evidence-based interventions as the students' progress is monitored (National Center on Response to Intervention, n.d.). Students with disabilities can also be identified during the RTI process (National Center on Response to Intervention, n.d.).

If the client does not respond to lower levels of intervention, such as teacher or peer modeling, then the therapist will conduct a full assessment of the child's speech and language skills. After the assessment, the therapist can recommend therapy and determine the therapy goals. The parents will meet with the therapist, the school counselor, and others to form an Individualized Education Plan (IEP) team. The team determines which services are warranted. Other services include but are not limited to occupational therapy and physical therapy. Once the team establishes the services, the goals, and signs the IEP, then it is a legal document and the client is placed on the school therapists' caseload. The therapist can then begin work towards helping the client meet their therapeutic goals. These goals are designed to address the student's specific communication or swallowing problems. 
As described in the Roles and Responsibilities of Speech-Language Pathologists in Schools (2010) it is important for speech therapists to "engage families in planning, decision making, and program implementation" (American Speech-Language-Hearing Association, 2010, p.3). The school SLP is expected to engage in prevention of failure in academics, assess for delays or disorders in children, provide necessary intervention for children, design supportive programs for the school, collect data on the children, and ensure progression of goals, and comply with all federal and state guidelines (American Speech-LanguageHearing Association, 2010). A school therapist must make sure that the goals addressed in therapy relate to education and educational success.

No Child Left Behind also requires Local Education Agencies to "review the effectiveness of activities to provide parent involvement," (NCLB Fact Sheet on Accountability, 2010, p. 3). This shows that the government sees the need for parents to be effectively involved in the school. As mandated by the Individuals with Disabilities Education Act (IDEA), students are entitled to a Free and Appropriate Public Education (FAPE); this means that students with disabilities or delays are entitled to services if it adversely impacts academics or the school process. Speech therapists are responsible for providing therapy to children with communication and swallowing difficulties (American Speech-Language-Hearing Association, 2010).

Therapy is often conducted in a therapist's office also known as the therapy room. Based on the therapeutic process, children receive therapy services in a variety of service delivery models, ranging from individual to small 
group; along with collaborative model, where the client may be seen in the classroom setting. When a client is seen on his or her own instead of with peers, then he or she is in individual therapy. The group setting is where more than one child come and receives therapy for their own individual goals. The clients can also be seen in the classroom setting to monitor progress, educate teachers and students, and provide overall classroom instruction.

Children in the school system are often not seen as often as those in a hospital setting and progress can be limited unless there is outside homework; "...it is common for clients in a hospital setting to be served 5-7 days of the week, whereas children seen in schools are typically served 2-3 times per week..." (Dwight, 2006, p. 126). Parent education has been shown to be important in the improvement of speech-language goals for children, as shown by The Hanen Centre (n.d.). Once the therapist educates the parents on how to complete the homework, it is up to the parents to complete the work at home. Parents are encouraged to set realistic communication goals for their children (The Hanen Centre, n.d.). The process of setting realistic communication goals for parents/guardians of school aged children is called the Individualized Education Plan (IEP). The IEP document is a result of parent and professionals intervention planning and setting goals for students age 3-21. The family and therapists work together to develop the goals for the child. The parent's input and approval of goals are ways for the parents to be empowered to be intentional about helping their child succeed. 
A strategy used by Yaruss, Coleman, \& Hammer (2006) is brainstorming. They encouraged parents to brainstorm ways to reduce stress (Yaruss, Coleman, \& Hammer, 2006). The stress was a potential cause for their child to become more dysfluent, or stutter (Yaruss, Coleman, \& Hammer, 2006). Scott (2010) contributed to the idea that each family has their own unique strengths and resources which can be used to help the client. Speech-language pathologists have implemented the importance of family resources in the form of an Individual Family Service Plan (IFSP). The IFSP is the document that is the result of parents and professionals working together to develop a plan and set goals for children birth to 3 years. The parents and their resources are included in the Individual Family Service Plan to help the child advance towards goals.

Parents already have the power to choose their child's goals in the IEP or IFSP. Perhaps if the parents of elementary children enrolled in speech and language therapy were empowered to choose the times they will help their children work on homework, then they would be more cooperative with the homework, instead of seeing it as something in which they have little input. The preschool program described by Delgado-Gaitan (1991) also stated that the teacher was striving for the parents to become co-teachers in the process. Speech-language pathologists desire parents to be co-teachers as well. They see their children much more often than the therapist and can help with generalization of goals. The Delgado-Gaitan (1991) research also states that "Essentially, the difference between parents who participate and those who do 
not, is that those who do have recognized that they are a critical part in their children's education" (p.31).

\section{Parents' power}

It is ideal for parents to be active participants in and out of the therapy room. Yaruss, Coleman, \& Hammer (2006) state that "If parents are involved in the decision-making process, it is often easier for them to 'own' the solution and become more active participants in the treatment process" (p. 121). DelgadoGaitan's 1991 research demonstrated an important aspect of parental involvement that L. Mercer, BSW, emphasizes; parents need to know and understand that what they do affects their child (personal communication, May 31 , 2010). Scott (2010) explains that evidence based practice demonstrates that the therapist, in their case a social worker, and the parents need to share their views on goals, tasks to complete the goals, budgets, and resources available. For the proposed research, the parents have already signed off on the IEP, so the long term goals and short term goals should already be aligned. The therapist and the parents need to share views in regards to their time budget and the resources available to complete the speech-language therapy homework.

\section{Homework}

Homework assignments can be sent home in order for students to practice what they have successfully completed in therapy (Roth \& Worthington, 2005). The extra practice can help the client with generalization (Roth \& Worthington, 2005). Generalization of a goal is when the target goal can be completed outside of the therapy room and without models, cues, or prompts. Sometimes it may be 
a goal to complete a task in a variety of settings outside the therapy room to establish generalization. This means that the client can successfully complete the task or target in functional communication settings during daily living activities. Generalization of goals is important because a student is not always in the therapy room. A client may be successful in the therapy room, but if they cannot be successful in their daily living, then the task has not generalized and become part of their everyday life.

Parents can help with the generalization by practicing the targets or tasks at home. The therapist can send home instructions or discuss the directions with the parents on how to successfully complete the homework (Roth \& Worthington, 2005).

There appears to be a lack of participation on the parents' part when it comes to speech-language therapy homework. It is unknown whether parents are not participating because they do not know what, when, why, or how to complete the homework. The current research study targets the "when" question: Does a video, which discusses implementation of homework in regards to frequency and duration, increase parents ability to implement homework and feel more important in their child's improvement in therapy? Perhaps parents do not know when to schedule time to work with their child on their homework. Many other fields have their own views on how to empower parents. These disciplines, along with their research, have added to the development of the current research study. 


\section{LITERATURE REVIEW}

According to Roth and Worthington (2005) speech and language therapy homework is to be given as practice only, not as something new to teach. Directions on how to complete the homework should be shared with parents consistently throughout therapy (Roth, \& Worthington, 2005). It is important for homework to be completed frequently (Stec, 2008). Parents or patients not participating with requested programs, homework, etc. have been a problem in a variety of fields including speech pathology, mental health, healthcare, social work, and education (Gance-Cleveland, 2005; Hoover-Dempsey, Bassler, \& Brissie, 1987; Lee, Greene, Hsu, Solovey, Grove, Fraser, Washburn, \& Teater, 2009; Lyons, O'Malley, O'Connor, \& Monaghan, 2010; and The Hanen Centre, n.d.). The lack of participation can cause lack of progress towards goals in a treatment plan, and conversely; benefits or gains can be seen when there is participation (Delgado-Gaitan, 1991; Gance-Cleveland, 2005; Lee, et al., 2009; The Hanen Centre, n.d; and Yaruss, Coleman, \& Hammer, 2006). Some field studies have found that empowering parents and patients, instead of telling them exactly what to do in every situation, has been a successful strategy in treatment goal completion. 


\section{Family focused interventions}

Having family-centered or family involved home-based care for clients is supported by Gance-Cleveland (2005), Hoover-Dempsey, Bassler, \& Brissie (1987), Lee, et al. (2009), and Stec (2008). Encouraging the parents to solve the problems and having guidance from professionals is supported by GanceCleveland (2005), Lee, et al. (2009), and Yaruss, Coleman, \& Hammer (2006).

Motivational interviewing is an idea which came about after healthcare professionals saw that children's progression towards goals was hindered when parents did not follow their recommendations (Gance-Cleveland, 2005). According to DiMatteo, Giordani, Lepper, \& Croghan (2002), as cited in GanceCleveland (2005), “...50\% of patients in the United States do not comply with the healthcare plan for treatment" (Gance-Cleveland, 2005, p.151). Motivational interviewing is another family-centered approach designed to increase adherence to treatment plans (Gance-Cleveland, 2005). Gance-Cleveland (2005) also shows encouraging statistics for the use of a family-centered, collaborative approach. Only $64 \%$ of patients follow the treatment plan when provided with knowledge and advice, but $85 \%$ follow the treatment plan when behavioral strategies and the family-centered, collaborative approach is used (GanceCleveland, 2005).

Integrated Family and Systems Treatment (I-FAST) is an evidence based home-based treatment program, which is used by the mental health field, created based on research evidence in order to treat families at risk for their child being removed from the home for treatment purposes (Lee, Greene, Hsu, Solovey, 
Grove, Fraser, Washburn, \& Teater, 2009). The I-FAST has some general assumptions about their clientele. One assumption suggests that families have resources and strengths which help them as they strive for change (Lee, et al., 2009). Within I-FAST, there is a focus on building and maintaining a good relationship with clients (Lee, et al., 2009). Another large part of the I-FAST is providing parents the tools to be able to solve problems on their own (Lee, et al., 2009). The mental health worker is encouraged to only step in as much as needed, so that the parent can be the one to solve the problem (Lee, et al., 2009). I-FAST also holds to the idea that the most benefit will come when all the parties involved (some call them stakeholders or stockholders) are working together (Lee, et al., 2009).

The treatment program in this study looked at 77 families with children or adolescents at risk for out of home treatment who had "...severe emotional or behavioral problems...," (Lee, et al., 2009, p. 397). They evaluated the families before the treatment, after the treatment, and 6 months after the treatment in order to determine if there was long term carry over after the IFAST program. They found "significant positive changes" in behavior which continued at the 6 month follow up (Lee, et al., 2009, p. 407). Such positive changes have been seen in the social work field (Mercer, 2010).

Yaruss, Coleman, \& Hammer (2006) explore parent strategies designed to benefit the parents as well as aid in progression of speech goals for the child who stutters (Yaruss, Coleman, \& Hammer, 2006). The treatment has parents brainstorm solutions, work with the therapist, and learn strategies to help their 
child at home (Yaruss, Coleman, \& Hammer, 2006). This study also states that “...if parents report that their schedule at home is busy and that they often feel rushed, then the parents and the clinician may brainstorm ways of reducing these time pressures" along with "If the parents are involved in the decision-making process, it is often easier for them to 'own' the solution and become more active participants in the treatment process" (Yaruss, Coleman, \& Hammer, 2006, p.121). The study found that the approach of having parents brainstorm their own solutions in partnership with lowering stress levels, may show benefits in regards to the improvement of the child's speech (Yaruss, Coleman, \& Hammer, 2006).

Teachers and principals of 66 schools participated in a study looking at their perceptions of parent involvement (Hoover-Dempsey, Bassler, \& Brissie, 1987). They were asked about parental involvement such as: conferences, volunteers, tutors, home instruction, and parent support" (Hoover-Dempsey, Bassler, \& Brissie, 1987). The parental involvement variables along with: average family socioeconomic status, teacher degree level, grade level distribution, average class size, teacher efficacy, organizational rigidity, principal perception of teacher efficacy and instructional coordination were examined (HooverDempsey, Bassler, \& Brissie, 1987). They found that if parents do not physically enter the school building during the school year, then they are much less likely to collaborate with the teachers (Hoover-Dempsey, Bassler, \& Brissie, 1987). Suggestions such as home instruction, shared responsibilities, etc were explained as beneficial (Hoover-Dempsey, Bassler, \& Brissie, 1987). It was also discussed that the principal needed to support the teachers in their efforts to 
interact with the parents, for parent-school interactions to be more successful (Hoover-Dempsey, Bassler, \& Brissie, 1987).

\section{Empowering and coaching}

To empower is to give ability to, give power to, or to enable. (Webster's new dictionary, 2004, p. 87 and Empower, n.d.). Empowering someone in the therapeutic process can be giving them the ability to understand the homework so they will practice, giving them power to believe they can be a great asset in the process, or enable them to use the resources they need in order to succeed. The idea of empowering parents to help their child comes from a variety of sources including Delgado-Gaitan (1991), L. Mercer, BSW (personal communication, May 31, 2010), The Hanen Centre (n.d.), and Scott (2010). The Salford Safeguarding Children Board created a guide to address the uncooperative behavior of families towards professionals (Salford Family Information Service, 2008). One of their suggestions was for therapists to obtain a written contract from the parent; this can help the parent intentionally focus on their responsibilities (Salford Family Information Service, 2008). Encouraging parents to be intentional about their child's homework can place more emphasis and importance on the homework. The Hanen Centre sees empowering parents as a way for the child to have more communication opportunities everyday. One preschool program, as described by Delgado-Gaitan (1991), empowered the parents to help their children by having the parents choose the topics they would learn about. This empowerment resulted in parents demonstrating more involvement in the program. 
A study by Delgado-Gaitan (1991) looked at ways to increase Spanishspeaking parent's involvement in school over the course of four years. They attempted to empower parents through social interactions in a learning environment (Delgado-Gaitan, 1991). A Preschool Program was developed as part of the learning environment (Delgado-Gaitan, 1991). Parents relayed to the teacher what they wanted to learn about, and the teacher put together an informative discussion group surrounding the needs and concerns of the parents (Delgado-Gaitan, 1991). The study found that cooperation between the parents and the school leads to more knowledge being shared (Delgado-Gaitan, 1991). In addition, the results indicated more communication between the parents and the school (Delgado-Gaitan, 1991).

Fetterman (2002) discussed the idea of an Empowerment Evaluation. The Empowerment Evaluation was created as a way for someone to coach or facilitate a client in order to accomplish 3 steps: establish a mission, take stock, and plan for the future (Fetterman, 2002). As with the I-FAST, there is a desire to have the client or the patient work on the goals they want and empower them to reach those goals (Fetterman, 2002). The Empowerment Evaluation has been used in many programs and agencies, including inner city schools and a national educational reform movement (Fetterman, 2002). It is set up to have the coach or facilitator support and brainstorm with the client as the client creates goals in areas of need, develops strategies to reach their goals, and discusses the impacts of reaching those goals (Fetterman, 2002). 
The Coaching 101 book and handbook discuss what coaching is, what it is not, and how to be an effective coach. As with the empowerment evaluation, the coach is meant to help the coachee (or client) with their goals. The Coaching 101 book explains that "Coaches walk alongside people through the whole process: clarifying goals, brainstorming plans, trying them out, revising them, trying again, and celebrating success" (Logan \& Carlton, 2003, p.23). This specific set of coaching materials is designed with a spiritual piece to the process (Logan \& Carlton, 2003). There are 5 main points in the coaching process each having specific questions specific questions to guide the conversation and coaching process: relate, reflect, refocus, resource, and review. Some of the questions outlined in the handbook, which relate to the current study include: "What obstacles are you facing? How committed are you? What will you do? (who, what, where, when, how) What resources do you already have? What resources will you need to accomplish your goals? What's working? What's not working? And What needs to change?" (Logan, \& Reinecke, 2003, p.5).

\section{Teaching and Training Parents}

Parents need assistance, teaching, and training when it comes to learning how to complete treatment programs for their children (Lyons, O'Malley,

O'Connor \& Monaghan, 2010; Maximize the Value Your Speech-Language Pathologist has for All Students, 2010; McNeill, Watson, Henington, \& Meeks, 2002; Metzl, 1980; Sandberg \& Liliedahl, 2008; The Hanen Centre, n.d.; and Vigil, Hodges, \& Klee, 2005). They may need support in order to complete it on their own at home (McNeill, Watson, Henington, \& Meeks, 2002). They may also 
require a support system (The Hanen Centre, n.d.). Parents may also need to be told what is expected of them in the therapeutic process (Lyons, O'Malley, O'Connor, \& Monaghan, 2010).

Three parent and child sets were researched to determine if there is a difference in communication patterns between people who use augmentative and alternative communication (AAC), and non-vocal children (Sandberg, \& Liliedahl, 2008). Augmentative and alternative communication includes ways of communicating without using oral speech. The three sets all had children who use AAC and could not use oral speech to effectively communicate (Sandberg, \& Liliedahl, 2008). They were observed during play interaction with the mother and child (Sandberg, \& Liliedahl, 2008). The study showed that parents need assistance when it comes to communicating effectively with their child who uses AAC (Sandberg, \& Liliedahl, 2008).

Parents may benefit from being taught specific language behaviors to model for their children. Sixty-four children participated in a study with their parents in order to compare parent-child communications with children who are typically developing in contrast to, parent-child communications with children who have a language delay (Vigil, Hodges, \& Klee, 2005). They were observed during a free play situation (Vigil, Hodges, \& Klee, 2005). The quantity of spoken communication was similar, yet the quality of the communication differed (Vigil, Hodges, \& Klee, 2005). The study emphasizes the need for therapists to provide training for parents on the language behaviors they should use and model for their children (Vigil, Hodges, \& Klee, 2005). 
Parents may need to be specifically taught enhancing infant development strategies (Metzl, 1980). The study discusses differences between parents receiving strategy teaching alone as compared to parents together with their spouse also receiving the teaching (Metzl, 1980). The evidence showed that parents could benefit from strategy training. It was suggested that in research only studying one parent may provide inaccurate results when two parents are involved with the child (Metzl, 1980).

McNeill, Watson, Henington, \& Meeks (2002) studied four parent training sessions designed to help the parent identify, analyze and intervene with their child's behavior problems. Four training sessions were designed to train parents on how to identify problems, complete an assessment, and create their own intervention for the problems (McNeill, Watson, Henington, \& Meeks, 2002). Specific behavioral strategies were taught to the parents during the sessions (McNeill, Watson, Henington, \& Meeks, 2002). Over the course of the four training sessions, there was an improvement in parental assessment skills (McNeill, Watson, Henington, \& Meeks, 2002).

The Hanen Program $\otimes$, also known as "It Takes Two to Talk", is a wellestablished family-centered early language intervention for young children with communication disorders (The Hanen Centre, n.d.). As with many of the other programs discussed, this program also focuses on empowering the parent (The Hanen Centre, n.d.). The program is designed to help the parent develop communication with their child on a daily basis (The Hanen Centre, n.d.). The parents are taught to find communication opportunities and how to take full 
advantage of those opportunities (The Hanen Centre, n.d.). It Takes Two to Talk supports the parents by providing a social aspect of the learning process.

Parents learn and communicate together about their experiences instead of one on one with the speech therapist (The Hanen Centre, n.d.).

Lyons, O'Malley, O'Connor, \& Monaghan (2010) conducted a study to determine what expectations and experiences parents have with children at the early intervention stage of life (Lyons, O'Malley, O'Connor, \& Monaghan, 2010). The speech-language pathologist and psychologist facilitated focus groups to discuss expectations, experiences, and develop a list of changes to be made (Lyons, O'Malley, O'Connor, \& Monaghan, 2010). In order for parents to connect in therapy, they needed to have better timing for therapy and to have their role explained as it pertains to the therapeutic process (Lyons, O'Malley, O'Connor, \& Monaghan, 2010). The need for parents and therapists to work together on the therapy development is emphasized in Lyons, et al. study (Lyons, O'Malley, O'Connor, \& Monaghan, 2010).

In conclusion, the goal is to empower parents to find the time to do the homework with their child. Glogowska and Campbell (2000) (in Lyons, O'Malley, O'Connor, \& Monaghan, 2010) state "A greater recognition of parents' feelings during their child's attendance at speech and language therapy might provide a means of facilitating their involvement and increasing their satisfactions with what happens" (p. 62). Parents may be able to increase their involvement by increasing the amount of speech language homework they do at home with their child. It is suspected that as the parent is intentional about scheduling time to do 
the homework, they will complete more speech and language homework, as well as gain confidence to complete the homework, thus supporting their child in making progress towards meeting his or her speech and language therapy goals. 


\section{METHODOLOGY}

\section{Participants}

The parents/guardians of elementary children who had a speech and language IEP were the target subjects for this study. The parents were recruited with the assistance of therapists from 14 schools of the 73 schools where contact was attempted. This was out of 89 total elementary schools from the large urban school district Jefferson County Public Schools (JCPS). Confidentiality was maintained by having therapists send home recruitment letters to the families. Each school was expected to have no more than 65 students on the speech therapist's caseload as outlined by KRS 334A.190 (Kentucky Revised Statutes, 2000). If the therapists were able to send home letters with each client, then the approximate number of parents receiving recruitment letters to participate in the research study totaled 910 .

\section{Materials}

The confidential questionnaires were designed by the researchers to assess the frequency, and duration of homework as well as the parents' perceived role in therapy homework. These questions were developed based upon the research from a variety of fields. Some questions were based off of the important questions asked within coaching: "What obstacles are you facing? How committed are you? What will you do? (who, what, where, when, how) What 
resources do you already have? What resources will you need to accomplish your goals? What's working? What's not working? and What needs to change?" (Logan, \& Reinecke, 2003, p.5).

The questionnaires were created using www.surveygizmo.com; a website which allows for confidentiality of hundreds of subjects. The questions about frequency and duration included: \#3 Do you work with your child on his/her speech therapy homework? \#4 How often per week are you supposed to work with them on their homework? How often per week are you working with your child on his/her homework? \#5 How many minutes per day are you supposed to work with them on their homework? How many minutes per day are you working with your child on his/her homework? \#13 Do you feel it's difficult to find time to work on your child's homework? Many questions were asked about parents' perceptions regarding therapy; these included: \#1 Have you been asked to work with your child's speech/language at home? \#2 Do you know the goals your child is working on in speech therapy? \#6 Do you feel comfortable working on your child's goals at home? \#7 Do you have questions on how to complete the homework? \#8 Do you feel you work with your child on their homework enough? \#9 Do you feel that you are an important part of your child's speech and language improvement? \#10 Do you feel your child's speech and language improves when they work with you and the therapist as opposed to only the therapist? \#11 Do you feel your child's speech-language therapist is helpful to you? \#12 Do you feel your child's speech-language therapist is helpful to your child? \#14 Do you feel your child can make progress towards his/her goals? \#15 
Do you feel that you can help your child make progress towards his/her goals? Question \#16 was asked as a measure to determine if parents viewed the video. Questions \#17, \#18, and \#19 were designed to compare data based upon marital status, income status, and the child's IEP classification. Finally, on questionnaire 2 (mid) and 3 (post), the participants were asked if they found the video helpful. This question was asked to determine if parents were able to find times to work on homework based on the support they were given by the video, or if outside factors influenced their responses.

Some questions were designed so that if a participant answered a specific way, then they were asked follow up questions. For example: \#3 Do you work with your child on his/her speech therapy homework?, if the participant answered No: then they were asked to check all that applied as a yes response "Is this because someone else (spouse, family member, etc) works with your child instead?," "Is this because you do not see your child often?," "Is this because you need more information from the therapist?" The follow up questions allowed for some clarification of the response without allowing for extraneous comments from the participant.

A video was designed by the researchers for this study based on the research on parent involvement and empowerment, to help the parents find time to work on their child's homework in their own busy schedules. Questions were designed to help the parents think on their own instead of being told when to complete the homework. Some questions were adapted from the coaching books. All of the questions were meant to empower the parents to find the time to do 
homework on their own. Suggestions were reserved for the end and intended to only be watched by those who had not developed a time to complete homework by the end of the video. The video was embedded within the questionnaires and was set up as a progressive slideshow. The sound added to the video was the text being read aloud slide by slide. Please see appendix 1 for the slides of the video.

Parents were expected to access questionnaires via the internet web addresses they were provided on the recruitment and reminder letters. They were to complete these from any computer of their choosing with internet access. The video they were asked to watch was embedded within the questionnaires. A video embedded within a questionnaire was a way to reduce participant burden. If they were asked to view the video on another website, some may not have chosen to view the video, some may have had complications navigating the website, and some may have been unsure how to view the video.

\section{Procedures}

The study was designed to examine the question "does a video, which discusses implementation of homework in regards to frequency and duration, increase parents ability to implement homework and feel more important in their child's improvement in therapy?" The design included the completion of a set of 3 confidential questionnaires via the internet, paired with the viewing of a video one to two times within a four week period. The thesis was reviewed and approved by the Institutional Review Board and approved 2/21/2011. It was also 
reviewed and approved by the Accountability, Research, and Planning Department of Jefferson County Public Schools on 2/24/2011.

Therapists in the Jefferson County Public Elementary Schools were asked to send home recruitment packets to parents one week before the initial questionnaire opened and to send home reminder letters out a few days prior to the second and third questionnaires. The recruitment packet included a letter explaining the study, which asked them to participate and provided them with the web addresses where they could access the questionnaires, along with the dates of when they were expected to complete each questionnaire. See figure 2 for the questionnaire.

Parents were asked to answer questions regarding their participation with their child's speech therapy homework, prior to watching the video intended to guide them to find time to work on their child's homework. After completing the pre-study questionnaire, they were asked to watch a video, and write down the times they decided to work on their child's homework. They were encouraged to try their new homework time for two weeks.

After the two weeks, they were asked to fill out the mid-study questionnaire. They were welcome to view the video again. They were asked to watch it and write down the times they decided to work on their child's homework. They may have found that the times they picked after the first video viewing worked, and that they did not wish to change the times. They would be welcome to write down the same times. However, if they found that they needed to change 
the times, then they were encouraged to write down the new times they decided to work on the homework.

One week later, they were asked to fill out the post-study questionnaire. They were asked the same questions to see if there was a difference between their pre, mid and post study questionnaires.

The video was intended to guide the parents in creating their own homework times instead of being told when to complete their child's homework. The parents were asked to come up with the times that they feel they could complete the homework. They were asked to time-line their days if they could not think of any gaps in their week to complete the child's speech therapy homework. If they did not feel that they could incorporate the homework, they were asked to think of other people (resources) they could utilize in order to complete the homework. No options/suggestions were provided until the end of the video. The parents were to design their own homework times. Once homework times had been established, the parents were to write down those times to help them remember. They were encouraged to write them down in a pocket calendar, on a family calendar, on the speech homework folder, or other option of their choosing that would help them remember their new found homework times. The times could have been a clock hour, a certain time after everyone gets home, during car rides to and from school, etc. See Figure 1 for a text version of the video.

The questionnaires included yes/no questions only. Yes/no questions were chosen instead of Liekart scale questions as to not skew data with non- 
decisive answers such as a neutral option of 3 . See Appendix Figure 2 for questionnaire questions.

\section{Main outcome measure}

The main outcome measure was to compare parental responses at two dates following the initial questionnaire and video. Pre-study (before viewing the video), mid study (2 weeks after viewing the video), and post study questionnaires were to be completed by the parents/guardians via an online questionnaire created for this study based on the research from the literature. The questionnaire results were to be compared to determine whether differences had occurred following the new interventions. The sign test would measure whether there is a positive difference, a negative difference, or no difference between the data sets. The pre and mid questionnaire data sets were to be analyzed by the sign test to determine a difference. The mid and post questionnaire data sets were to be analyzed by the sign test to determine a difference. The pre and post questionnaire data sets were to be analyzed by the sign test to determine a difference. It was expected that the post study questionnaire would show a positive difference when compared to the pre and mid study questionnaires. These statistical analyses were not run due to no data with which to compare the pre, mid, and post study questionnaires. 


\section{RESULTS}

It was hypothesized that the post study questionnaires would show a positive difference as compared to the pre and mid study questionnaires. Therefore, the hypothesis was that the video may have made a positive difference in the frequency and duration of parent homework implementation and positive parental perceptions. However, no one participated throughout the length of the study.

Initial contact was made to therapists in 73 out of 89 schools in JCPS. Only 58 of the 73 were successful contacts, meaning that a message was able to be relayed to the therapist or direct contact was made. The therapists' whose emails were available on the school's website were contacted first. Some of the emails were undeliverable. Some of the therapists who did not e-mail back were called. Of the ones called, some answered and said yes, some answered and said no; some did not answer and a message was left, and some did not answer and there was no option to leave a message.

The therapists whose e-mail information was unavailable on the school's website were then contacted via phone. Once 14 schools said yes, it appeared that there would be over 900 parents getting letters which was decided as sufficient for research. Of the schools who decided not to participate, some did 
not provide reasons, but 10 schools explained that they did not give homework to their students.

Twenty-four percent, (14/58) of the contacted SLPs initially agreed to participate, $28 \%$ (16/58) declined participation, and 48\% (28/58) did not respond. The therapists of 14 schools were given a packet of information containing all of the necessary papers to send home to the parents regarding the research study. The recruitment letter, the reminder letters, and the letter to the therapist were all included in each schools packet. The therapists were given the packets on Monday March 7, except for one school, who got their packet Tuesday morning March 8. The recruitment letters were to be handed out to parents that week as early as possible. Of the $24 \%$ who initially agreed to participate, it is known that 4 schools failed to distribute the recruitment letters. Fourteen percent or less of the schools who agreed to participate actually distributed the recruitment packet. The parents were given until the following Sunday night at midnight to complete the initial questionnaire. There were no responses by Sunday March 13 at midnight; at that time the initial questionnaire had closed.

Three people took part in the second questionnaire. None of the participants watched the video or responded in any other questionnaire, therefore, there is no data to compare, nor any data regarding the video effectiveness. Two of the three participants did not complete the entire questionnaire. Since there were no initial questionnaires completed, there was no data with which to compare the second questionnaire responses. The initial questionnaire was the only one which included questions regarding martial status, income status, and 
the child's IEP classification. The responses were to be tracked from the initial questionnaire. It was unexpected that the second questionnaire would be the only one to receive any responses; therefore no information about marital status, income status, or the child's IEP classification exists.

All of the participants were asked to work on their child's homework, they knew the goals, they work on the homework, and they feel comfortable working on the homework. Two completed homework as often and as many minutes as the therapist requested. One completed homework less often than requested, but as many minutes as requested. Two people did not feel that they worked on their child's speech homework enough, however one of those responders answered that they completed the homework as often and as many minutes as requested by the therapist. Only one participant responded to the final questions on the questionnaire. That participant felt that they are an important part of their child's improvement, that their child's speech improves when they work with the therapist as opposed to only the therapist, that the therapist is helpful to both the parent and the child, and that their child can make progress and they can help with that progress. The participant did not feel that it was difficult to find time to work on their child's homework. This participant was the same participant who did not complete homework as often as requested.

One therapist responded via e-mail that all of the recruitment letters had been sent home. One parent responded via e-mail commenting that homework had been requested, but not provided from the therapist. One therapist 
responded, 3 days after the first questionnaire had closed, that due to clients not receiving homework at this time the letters would not be sent home.

Therapist/School Contacts:

No successful contact made to the school (no answer on phone or undeliverable e-mail): 15 schools

Contacted once, with no return contact from therapist: 26 schools

Contacted twice, with no return contact from therapist: 2 schools

- A school mentioned that some therapists work at more than one school, which could account for some of the perceived no return contact.

\section{Contact and Responses}

Not willing to send home recruitment letters: 16 schools

Reasons provided:

- Did not expect good feedback

- Did not assign homework or rarely assigned homework (7 responded that they did not assign homework)

- Parents got upset about homework

- Trying to tell the parents how to do it took away from therapy time (did give homework in the past just not this year)

- Did not have good parent involvement

- Parents did not come to parent teacher conferences, and they tended to not participate in the therapy process

- Homework was sent home but never completed or returned 
- Due to unsuccessful homework over a period of time, the therapist discontinued sending homework

- Children did not turn in regular classroom homework along with not turning in speech therapy homework

- Few parents had internet

- $67.5 \%$ of elementary students received a free or reduced-priced meals, indicating that families were low-income which possibly indicated that they did not have the money to have the internet or computer (Jefferson County Public Schools, 2011 p. 5)

- Paperwork was overwhelming without adding on research paperwork or materials

Yes, willing to send home recruitment letters: 14 schools

Side notes/stipulations from five therapists:

- May send home articulation work but did not call it homework

- Maybe, no other communication

- Concerned over parents potential lack of access to computers

- Wanted to check with principal first, no other communication Response from those willing to send home recruitment letters: 5 schools

- Four therapists mentioned that they either did not get all of the letters sent home or they sent the letters late Reasons included:

- Busy schedule

- Did not give homework at that time 
- Not at school that week

- Forgot

- One therapist did confirm that all of the letters were sent home on time for the initial questionnaire. This confirmed that approximately 65 students received the recruitment letters, which means that less than $14 \%$ of the anticipated parents may have received the recruitment letters.

\section{Parental Responses:}

- Letters were sent too late in order for the parents to respond on time: 1 parent

- Confused about whether to participate if the family was not given homework: 1 parent 


\section{DISCUSSION}

Jefferson County Public Schools (JCPS) are in the largest school district in Kentucky (Jefferson County Public Schools, Louisville, Kentucky, n.d.). There are approximately 36,829 students in the elementary schools, 7,375 in kindergarten, and 4,761 in preschool in JCPS (Jefferson County Public Schools, 2011, p.4). For a school district this large, the potential participant population is much greater than neighboring smaller districts. Even with such a large potential participant population, there was still unsuccessful participation. JCPS have great diversity among each school. They have $50.8 \%$ Caucasian students, $36.3 \%$ African American students, 5.4\% Hispanic/Latino students, 2.8\% Asian students, $0.1 \%$ American Indian students, and $4.3 \%$ of students are other ethnicities (Jefferson County Public Schools, 2011, p. 4).

The problems outlined above, combined with zero responses on the initial questionnaire, raise concerns about the lack of participation of parents in the speech therapy process. There are a variety of possible contributing factors to the lack of participation. There are possible contributing factors to why no one filled out the initial questionnaire and there are possible contributing factors to why parents do not participate in the therapy process. 
Some of the possible contributing factors to parents not participating in the research were touched on by some of the speech therapists. The possible contributing factors include:

- Parents may not have a computer or internet access.

- Therapist may not have handed out the recruitment letters to all clients.

- Clients may not have taken the letters home.

- Parents may not have received the letters from their child in time to take the questionnaire.

- Parents did not receive homework from the therapist and therefore did not feel the need to take the questionnaire.

- Parents may not have felt the questionnaire was important.

- Parents may not be participating in the homework and feel uncomfortable taking part in research that discusses lack of participation.

- Parents may not have time in their busy schedules to take part in research.

- Parents are not involved in the entire school process, and therefore are much less likely to be involved in the therapy process.

This list is not exhaustive, it would be impossible to predict every possible contributing factor in each family, however, this list can give insight to where more research may need to be conducted.

Some of the possible outside contributing factors resulting in a null participation include:

- The child did not put letter in the backpack. 
- The child did not bring their backpack home.

- The child did not hand their parent the letter.

- The parent was not available for participation ( on business trip...).

- The parent did not open letter in time to participate.

- The parent chose not to respond.

- The parent did not check child's backpack.

- The therapist did not receive information.

- The therapist did not read information.

- An illness prevented participation (therapist, parent, child).

- The therapist chose not to participate by not handing out the letters.

- The therapist did not get the information out in a timely manner.

- The school did not get the information to therapist.

- The school chose not to participate.

Some of the possible contributing factors to parents not participating in therapy homework include:

- Parents do not receive homework.

- Parents do not have time to complete homework.

- Parents do not know how to complete homework.

- Parents do not know their child has homework.

- Parents do not feel the speech homework is important.

- Parents cannot read.

- The child lives with someone other than the parent.

- The child lives in two locations (shared custody). 
Although some participants did take part in the second questionnaire, due to the limited responses and the lack of a comparison questionnaire, it is difficult to make definitive conclusions regarding the effects of the video on empowering parents to complete speech and language homework. All of the participants were receiving homework, all of them felt they had the time to complete homework, all of them knew how to complete the homework, all of them knew their child had homework, and all of them felt that the homework was important. It is unclear what the cause was for one participant to not complete the homework as often as requested.

Concerns were raised about how to participate if the parents were not given homework. Since many schools shared that they do not send home speech therapy homework, there could have been other confused parents who decided not to participate due to them not receiving any homework. Even though they were not given homework, there were several questions that they could have answered which could have provided more insight into the parents' perspectives of homework.

The lack of participation in the research study does not directly correlate with parents not participating in speech homework. However, it is cause for more research to determine why parents are not participating in speech homework. Some therapists mentioned that they used to give homework, but due to the lack of parent participation, they ceased to send homework with the child. There are many variables that could have been in play in the initial questionnaire not receiving any responses. 
In order to attempt this study again, some changes may be considered. Parents may need to be given the questionnaire and video opportunity when they are on school grounds in order for more direct contact with the parents. Another option is to obtain parents e-mails or home addresses and send the letters directly to them. Some participants may desire an incentive to complete a four week research. Perhaps it would be beneficial to recruit participants to come to a center where they can take the questionnaire, view the video, and offer any comments while they are there. Perhaps participants could be recruited to come to a center where they could take the questionnaire, view the video, offer comments, and return to the center to complete the remainder of the study. More research needs to focus on parent participation. The therapy process is designed to create change and help clients reach their goals. If the therapy process is going to be successful, then more practice needs to be completed at home. Regardless of work and after school care, most children are at home more than they are at school. The parents are the ones who can help the children remember to practice and have quality practice time. Are parents not participating because they do not know when to work on homework, they do not know why they should work on homework, they do not know how to work on homework, or they don't know what to work on? Do children complete their homework for regular courses and not speech homework? Is there a difference between completing homework for a graded course versus speech therapy? Would parents be more or less likely to participate in homework if it was available via a web-based homework program? 
Learning more about parent participation and lack of participation could have dramatic impacts on the speech-language pathology field. Identifying the true underlying problem(s) as to why parents do not work on homework could help therapists directly address such issues. If the identified issues were directly addressed, then there should be an increase in parent participation, which could decrease the amount of time a child needs to remain in therapy due to an increase in goal achievement. 


\section{REFERENCES}

American Speech-Language-Hearing Association. (2010). Roles and Responsibilities of Speech-Language Pathologists in Schools.

[Professional Issues Statement]. Available from www.asha.org/policy. doi:10.1044/policy.PI2010-00317

Delgado-Gaitan, C. (1991). Involving parents in the schools: a process of empowerment. American Journal of Education, 100(1), 20-46. Retrieved from http://www.jstor.org/stable/1085651

DiMatteo, M.R., Giordani, P.J., Lepper, H.S., \& Croghan, T.W. (2002). Patient adherence and medical treatment outcomes: A meta-analysis. Medical Care, 40(9), 794-811.

Dwight, D. M. (2006). Here's how to do therapy: hands-on care skills in speechlanguage pathology. San Diego: Plural Pub.

Empower. (n.d.). Collins English Dictionary - Complete \& Unabridged 10th Edition. Retrieved April 05, 2011, from Dictionary.com website: http://dictionary.reference.com/browse/empower

Fetterman, D. M. (2002). Empowerment Evaluation: Building Communities of Practice and a Culture of Learning. American Journal of Community Psychology, 30(1), 89-102. doi: 0091-0562/02/0200-0089/0

Gance-Cleveland, B. (2005). Family-Centered Care: Motivational interviewing as a strategy to increase families' adherence to treatment regimens. Journal for Specialists in Pediatric Nursing, 10(3), 151-155. doi:10.1111/j.17446155.2005.00028.x

Hogue, A., Dauber, S., Faw Stambaugh, L., Liddle, H. A., \& Cecero, J. J. (2006). Early Therapeutic Alliance and Treatment Outcome in Individual and Family Therapy for Adolescent Behavior Problems. Journal of Consulting \& Clinical Psychology, 74(1), 121-129. doi:10.1037/0022-006X.74.1.121 
Hoover-Dempsey, K.V., Bassler, O.C., \& Brissie, J.S. (1987). Parent involvement: contributions of teacher efficacy, school socioeconomic status, and other school characteristics. American Educational Research Association, 24(3), 417-435. Retrieved from http://www.jstor.org/stable/1163118

Jefferson County Public Schools (2011). Jefferson County Public Schools Facts 2011. Retrived March 22, 2011, from http://www.jefferson.k12.ky.us/Pubs/Facts_Booklet.pdf

Jefferson County Public Schools, Louisville, Kentucky. (n.d.). Jefferson County Public Schools, Louisville, Kentucky. Retrieved March 22, 2011, from http://www.jefferson.k12.ky.us/employee/Classified.html

Kentucky Revised Statutes. (2000). Kentucky Legislature 334A.190 Caseload limitations for speech-language pathologists in the public schools. Retrieved March 30, 2011, from http://www.lrc.ky.gov/krs/334a00/190.pdf

Lee, M. Y., Greene, G. J., Hsu, K. S., Solovey, A., Grove, D., Fraser, J. S., Washburn, P., \& Teater, B. (2009). Utilizing Family Strengths and Resilience: Integrative Family and Systems Treatment with Children and Adolescents with Severe Emotional and Behavioral Problems. Family Process, 48(3), 395-416. doi: 10.1111/j.1545-5300.2009.01291.x

Logan, R. E., \& Carlton, S. (2003). Coaching 101: Discover the Power of Coaching. St. Charles: Churchsmart Resources.

Logan, R. E., \& Reinecke, G. B. (2003). Coaching 101 Handbook. St. Charles: Churchsmart Resources.

Lyons, R., O'Malley, M. P., O'Connor, P., \& Monaghan, U. (2010). 'It's just so lovely to hear him talking': Exploring the early-intervention expectations and experiences of parents. Child Language Teaching and Therapy, 26(1), 61-76. Retrieved from EBSCOhost http://search.ebscohost.com/login.aspx?direct=true\&db=aph\&AN=497462 96\&site=ehost-live

Maximize the Value Your Speech-Language Pathologist has for All Students. (2010). American Speech and Hearing Association Website. Retrieved April 4, 2011, from http://www.asha.org/uploadedFiles/advocacy/schoolfundadv/4011FactShe et.pdf\#search=\%22parent\%22 
McNeill, S. L., Watson, T. S., Henington, C., \& Meeks, C. (2002). The Effects of Training Parents in Functional Behavior Assessment on Problem Identification, Problem Analysis, and Intervention Design. Behavior Modification, 26(4), 499. doi: 10.1177/0145445502026004004

Metzl, M. (1980). Teaching Parents a Strategy for Enhancing Infant Development. Child Development, 51(2), 583-586. doi:10.1111/1467-8624.ep12329702

National Center on Response to Intervention. (n.d.). National Center on Response to Intervention (RTI) - Home. Retrieved April 5, 2011, from http://www.rti4success.org/

NCLB Fact Sheet on Accountability. (2010). American Speech and Hearing Association Website. Retrieved April 4, 2011, from http://www.asha.org/uploadedFiles/advocacy/federal/nclb/NCLBFactsAcco untability.pdf\#search=\%22parent\%22

Roth, F. P., \& Worthington, C. K. (2005). Treatment resource manual for speechlanguage pathology (3rd ed.): Australia: Thomson Delmar Learning.

Salford Family Information Service. (2008). Working with uncooperative families. Retrieved from http://services.salford.gov.uk/sscbmanual/chaptersp_work_uncoop.htm

Sandberg, A., \& Liliedahl, M. (2008). Patterns in early interaction between young preschool children with severe speech and physical impairments and their parents. Child Language Teaching \& Therapy, 24(1), 9-30. doi: 10.1177/0265659007084566

Scott, Pam PhD, MSW, LISW-S, LICDC. (2010). I-FAST: Integrative family and systems treatment [PowerPoint slides, handouts, and lecture notes].

Stec, J. (2008). Division of Speech Pathology: Speech Therapy at School. American Speech and Hearing Association Convention. Retrieved April 4, 2011, from www.asha.org/Events/convention

The Hanen Centre. (n.d.). It takes two to talk: The Hanen program for parents research summary. Retrieved from http://www.hanen.org/web/Portals/0/HostedFiles/ITTTResearchSummary. pdf

Understanding Speech-Language Pathology. (2010). American SpeechLanguage-Hearing Association | Progress Us Therapy. Retrieved April 4, 2011, from http://www.asha.org/uploadedFiles/BHSMParentsFactSheet.pdf 
Vigil, D. C., Hodges, J., \& Klee, T. (2005). Quantity and quality of parental language input to late-talking toddlers during play. Child Language Teaching \& Therapy, 21(2), 107-122. doi:10.1191/0265659005ct284oa

Webster's new dictionary (p. 87). (2004). empower. S.I.: Promotional Sales Books.

Yaruss, J., Coleman, C., \& Hammer, D. (2006). Treating Preschool Children Who Stutter: Description and Preliminary Evaluation of a Family-Focused Treatment Approach. Language, Speech \& Hearing Services in Schools, 37(2), 118-136. Retrieved from EBSCOhost http://search.ebscohost.com/login.aspx?direct=true\&db=aph\&AN=207251 79\&site=ehost-live

Young, S., \& Young, G. (2009). The young children's academy: Because a great start lasts a lifetime parent's handbook. Retrieved from http://www.tyca.net/LinkClick.aspx?fileticket=UYht8QbyBaQ=\&tabid=155\& mid $=515$ 


\section{APPENDIX}

\section{Appendix Figure 1}

The video was embedded within the questionnaires and was set up as a progressive slideshow. The sound added to the video was the text being read aloud slide by slide.

\section{Parents/Guardians}

Thank you for participating in this research study.

\section{When to do homework?}

- Do you run out of time at the end of the day?

- Do you always feel as though you are too busy to complete the homework with your child?

- Do you simply forget to complete the homework? 


\section{Let's Brainstorm!}

- Think about all of your resources

- Who?

- Who do you have for support? Who could come along side you to help?

- What?

- What do you have on your schedule? What could be rearranged?

- Where?

- Where do you do the homework? Where else could you do the homework?

- When?

- When do you do the homework? When else could you do the homework?

\section{Keep thinking...}

- Think about those questions: Who, What, Where, and When.

- What's keeping you from being able to accomplish the homework with your child?

- What needs to happen in order for you to be able to complete the homework?

- Write down anything you may find helpful.

\section{Try this!}

- Try thinking of times when you are with your child.

- When do you see your child?

- When do you have a chance to work with your child?

- When do you both have time together? 


\section{Didn't work?}

- Brainstorm some ideas about when you could spend time with your child.

- Go ahead and think about or write down any time that might work.

- Feel free to write down everything you do from the time you get up until the time you go to bed. See what time you might have that you could spend with your child on the homework.

\section{Schedule}

- You may want to...

- Try to write out your schedule and your child's schedule to compare them.

- Write out what you do in 15,30 , or 60 minute increments.

- Color the blocks of time that are flexible.

- Circle the times when you are together.

\section{If you found a time...}

- Write it down

- In your planner

- In your phone

- On a family calendar

- On your child's speech folder

- Anywhere that will help you remember when you are going to work with your child on his or her speech language homework. 


\section{Still having trouble?}

- If you already found a time that will work, stick with it.

- If not, consider these suggestions.

- Try it in the car

- On the way to and from school, to and from ball practice, to and from picking up a sibling, etc.

- Have one on one time

- Have a family member, friend, or neighbor watch your other children, do the homework while the other children are doing schoolwork, go for a walk, choose a time when your child is most cooperative, etc.

- Try it while you are completing chores

- Washing the dishes, folding laundry, cooking a meal, etc.

- Rearrange the schedule

- Change meeting or appointment times to fit your child's schedule, homework before dinner, homework before computer, etc.

\section{Now get to it!}

- For the next two weeks, make it a point to spend that time that you just carved out to be with your child and help your child with the speech and language homework.

- Come back to the website on 2/25/11 and complete the second questionnaire.

- Thank you for your time and cooperation! 


\section{Appendix Figure 2}

Questionnaire: each question had yes/no boxes available unless they were able to choose between items as shown below.

1. Have you been asked to work with your child's speech/language at home?

2. Do you know the goals your child is working on in speech therapy?

If the answer is No,

Is this because the IEP recently changed?

Is this because you have not seen the IEP?

Is this because you need to discuss them with the speech therapist?

3. Do you work with your child on his/her speech therapy homework?

If No,

Is this because someone else (spouse, family member, etc) works with your child instead?

Is this because you do not see your child often?

Is this because you need more information from the therapist?

4. How often per week are you supposed to work with them on their homework?

0-1 day

2-3 days

3-5 days

6-7 days

How often per week are you working with your child on his/her homework?

0-1 day

2-3 days 
3-5 days

6-7 days

5. How many minutes per day are you supposed to work with them on their homework?

$\square$ 0-10 minutes per day

11-20 minutes per day

21-30 minutes per day

Over 30 minutes per day

How many minutes per day are you working with your child on his/her homework?

0-10 minutes per day

$11-20$ minutes per day

21-30 minutes per day

$\square$ Over 30 minutes per day

6. Do you feel comfortable working on your child's goals at home?

If No,

Do you feel you need more help from the speech therapist?

7. Do you have questions on how to complete the homework?

If Yes,

Do you feel you need a meeting with the speech therapist?

Do you feel uncomfortable asking the speech therapist for help?

Have you tried contacting the speech therapist but they didn't contact respond? 
8. Do you feel you work with your child on their homework enough?

9. Do you feel that you are an important part of your child's speech and language improvement?

10. Do you feel your child's speech and language improves when they work with you and the therapist as opposed to only the therapist?

11. Do you feel your child's speech-language therapist is helpful to you?

12. Do you feel your child's speech-language therapist is helpful to your child?

13. Do you feel it's difficult to find time to work on your child's homework?

If Yes,

Is it difficult because you do not see your child often during the day?

Is it difficult because you have a busy family schedule?

Is it difficult because you have a busy work schedule?

14. Do you feel your child can make progress towards his/her goals?

15. Do you feel that you can help your child make progress towards his/her goals?

Inserted embedded video

16. Did you watch the video above?

Questionnaire one had the following questions that Questionnaire 2 and 3 did not:

17. Please select your marital status:

$\square$ Married

Never Married

Divorced 
Widowed

Separated

18. Please select your family's estimated gross income:

Less than $\$ 15,000$

$\$ 15,000$ to $\$ 24,999$

$\$ 25,000$ to $\$ 34,999$

$\$ 35,000$ to $\$ 49,999$

$\$ 50,000$ to $\$ 74,999$

$\$ 75,999$ to $\$ 99,999$

$\$ 100,000$ to $\$ 149,999$

$\$ 150,000$ to $\$ 199,999$

$\$ 200,000$ or more

19. Does your child have a speech and language only IEP?

If No,

Please select the classification your child has on his/her IEP

Autism

Developmental Delay

Intellectual Impairment

Sensory Impairment (Hearing Impairment or Deaf) (Vision Impairment or Blind) (Deafblind)

Neurological Impairment

Emotional Impairment

Communication Impairment 
$\square$ Physical Impairment

$\square$ Health Impairment

Specific Learning Disability

Questionnaire 2 and 3 had the following question:

20. Did you find the video helpful?

If No,

$\square$ is it because you were unable to review it during the last 2 weeks?

$\square$ Is it because time is not the problem when it comes to completing your child's speech and language homework? 
Second Questionnaire Responses

\begin{tabular}{|l|l|l|l|l|l|l|l|}
\hline & $\begin{array}{l}\text { Have you been } \\
\text { asked to work } \\
\text { with your child's } \\
\text { speech/language } \\
\text { at home? }\end{array}$ & $\begin{array}{l}\text { Do you know } \\
\text { the goals your } \\
\text { child is } \\
\text { working on in } \\
\text { speech } \\
\text { therapy? }\end{array}$ & $\begin{array}{l}\text { Do you work } \\
\text { with your child } \\
\text { on his/her } \\
\text { speech therapy } \\
\text { homework? }\end{array}$ & $\begin{array}{l}\text { How often per week } \\
\text { are you supposed } \\
\text { to work with your } \\
\text { child on his/her } \\
\text { homework? }\end{array}$ & $\begin{array}{l}\text { How often per } \\
\text { week are you } \\
\text { working with your } \\
\text { child on his/her } \\
\text { homework? }\end{array}$ & $\begin{array}{l}\text { How many minutes } \\
\text { per day are you } \\
\text { supposed to work } \\
\text { with them on their } \\
\text { homework? }\end{array}$ & $\begin{array}{l}\text { How many } \\
\text { minutes per day } \\
\text { with your child on } \\
\text { his/her } \\
\text { homework? }\end{array}$ \\
\hline 1 & Yes & Yes & Yes & $2-3$ days & $2-3$ days & $11-20$ \\
\hline 2 & Yes & Yes & Yes & $4-5$ days & $0-1$ days & $0-10$ \\
\hline 3 & Yes & Yes & Yes & $6-7$ days & $6-7$ days & $11-20$ \\
\hline
\end{tabular}

\begin{tabular}{|c|c|c|c|c|c|c|c|}
\hline Response ID & $\begin{array}{l}\text { Do you feel } \\
\text { comfortable } \\
\text { working on your } \\
\text { child's goals at } \\
\text { home? }\end{array}$ & $\begin{array}{l}\text { Do you need } \\
\text { more help } \\
\text { from the } \\
\text { speech } \\
\text { therapist? }\end{array}$ & $\begin{array}{l}\text { Do you have } \\
\text { questions on } \\
\text { how to complete } \\
\text { the homework? }\end{array}$ & $\begin{array}{l}\text { Do you feel you } \\
\text { work with your child } \\
\text { on their homework } \\
\text { enough? }\end{array}$ & $\begin{array}{l}\text { Do you feel that } \\
\text { you are an } \\
\text { important part of } \\
\text { your child's } \\
\text { speech and } \\
\text { language } \\
\text { improvement? }\end{array}$ & $\begin{array}{l}\text { Do you feel your } \\
\text { child's speech and } \\
\text { language improves } \\
\text { when they work with } \\
\text { you and the } \\
\text { therapist as } \\
\text { opposed to only the } \\
\text { therapist? }\end{array}$ & $\begin{array}{l}\text { Do you feel your } \\
\text { child's speech- } \\
\text { language therapist } \\
\text { is helpful to you? }\end{array}$ \\
\hline 1 & Yes & NR & No & Yes & NR & $\mathrm{NR}$ & NR \\
\hline 2 & Yes & NR & No & No & Yes & Yes & Yes \\
\hline 3 & Yes & NR & No & No & NR & NR & NR \\
\hline
\end{tabular}

\begin{tabular}{|l|l|l|l|l|l|}
\hline & $\begin{array}{l}\text { Do you feel your } \\
\text { child's speech- } \\
\text { language } \\
\text { therapist is helpful } \\
\text { to your child? }\end{array}$ & $\begin{array}{l}\text { Do you feel } \\
\text { it's difficult to } \\
\text { find time to } \\
\text { work on your } \\
\text { child's } \\
\text { homework? }\end{array}$ & $\begin{array}{l}\text { Do you feel your } \\
\text { child can make } \\
\text { progress } \\
\text { towards his/her } \\
\text { goals? }\end{array}$ & $\begin{array}{l}\text { Do you feel that you } \\
\text { can help your child } \\
\text { make progress } \\
\text { towards his/her } \\
\text { goals? }\end{array}$ & $\begin{array}{l}\text { Did you watch the } \\
\text { video above? }\end{array}$ \\
\hline 1 & NR & NR & NR & NR & NR \\
\hline 2 & Yes & No & Yes & Yes & No \\
\hline 3 & NR & NR & NR & NR & NR \\
\hline
\end{tabular}

$N R=$ No Response 


\section{CURRICULUM VITAE}

NAME: $\quad$ Lana Ridge

ADDRESS: $\quad 819$ Foxwood Avenue, Louisville, Kentucky, 40223

DOB: $\quad 02 / 06 / 1987$

EDUCATION

\& TRAINING: B.S., Miami University Oxford, $\mathrm{OH}$ 2005-2009

PROFESSIONAL SOCIETIES: National Student Speech Language Hearing Association Member, 2009 - 2011

Kentucky Speech-Language and Hearing Association Member, 2010-2011

INVITED PRESENTATIONS: Dynavox Vmax Eyegaze demonstration K.I.D.S. Center

April 2011

Seizure knowledge, awareness, and response.

Miami University, Speech Pathology and

Audiology Department

September 2008

Miami University, Education Department October 2008

Miami University, Health Department November 2008 